\title{
A informatização nos processos de análise editorial
}

\author{
Harley E. A. Bicas
}

Ainda vivenciando os momentos de glória e as emoções decorrentes da difícil conquista dos Arquivos Brasileiros de Oftalmologia, a almejada admissão na base de dados MEDLINE, causa-nos novo orgulho apresentarmos mais uma iniciativa de consolidação do prestígio dessa nossa revista e de ascensão na categoria de sua eficiência: a de agilização de suas decisões editoriais.

É óbvio que a indexação pela MEDLINE acarreta mais responsabilidades e trabalhos, mas a novidade que agora se anuncia corresponde a um projeto independente dessa ligação, que já se gerava e deveria ser concretizado mesmo que aquela pudesse mais demorar. Certamente, todavia, tais novas ações já se incorporam como fatores favoráveis às necessidades dos novos tempos e vem como prováveis soluções a um de nossos problemas: o da relativa morosidade no julgamento das matérias enviadas à publicação.

De fato, os cuidados para com a qualidade dos artigos recebidos para publicação, fazem-nos submetidos a um processamento no qual os rigores da análise são requeridos aos julgadores e modos pedagógicos incentivados em suas respostas. Tudo no sentido de garantir que eventuais erros ou omissões fiquem escoimados do produto final, que autores sejam protegidos de uma exposição inadequada, ou ajudados a melhores apresentações; e que os leitores tenham uma oferta de matérias depuradas. Isso leva tempo. É verdade que nem sempre um longo intervalo entre a chegada do artigo à secretaria dos Arquivos Brasileiros de Oftalmologia e sua publicação, possa ser atribuído à demora da revisão e a nossos trâmites burocráticos. Não poucas vezes são os próprios autores os que retardam o processo, pelo atraso na devolução do artigo corrigido, em suas diferentes fases de aprimoramento. Mas, infelizmente, não podemos fugir à responsabilidade das demais dilações, quer por estagnação da análise por um ou mais revisores, quer pelo alongamento de prazos na toma- da de decisões por editores, quer por protelações determinadas pelo acúmulo de serviços, na secretaria.

As aplicações desse processo de consultas e correções, entre a revista, conselheiros editoriais e autores, têm sido pelos métodos tradicionais de comunicação, usando correios. Mas tempos modernos exigem os novos, eletrônicos, que a partir de agora serão implantados. É claro não se pensar que a demora tomada entre o envio e a recepção da correspondência pelos correios, comparada à da eventual instantaneidade da via eletrônica, justifique os atuais prazos de publicação: a diferença desses dois métodos é relativamente irrisória. Mas ao lado da transmissão mais rápida, o próprio controle burocrático dos fluxos, o de verificação de revisores já acionados, enfim, todo o processo de distribuição, cobranças, recepção e eventual retomada do ciclo (em parte já informatizado) deverá produzir desembaraços e mais eficiência.

Na implantação dessas condições, não apenas o Conselho Brasileiro de Oftalmologia estará contribuindo, mas também o CNPq por meios de dotação especifica (Proc. 400374/03-0). Alguns outros aspectos relacionados a essa nova modalidade de processamento de análises editoriais são explicitados em editorial à parte.

É de se prever que a atualização da sistemática operacional dos Arquivos Brasileiros de Oftalmologia, uma legítima aspiração dos autores de seus artigos e inequívoca obrigação de seus editores quanto a propósitos de rapidez e eficiência de suas análises, deva ainda transitar com algumas dificuldades em seu início, até adaptações dos agentes envolvidos. De qualquer modo, embora o mecanismo tradicional de expedições postais permaneça ainda tolerado a autores que por ele optarem, as transmissões eletrônicas tornar-se-ão compulsórias aos analistas dos trabalhos, rotina nas comunicações entre estes e a secretaria da revista, e dela com os autores que a preferirem.

\section{Ao enviar um artigo para publicação, leia ATENTAMENTE as instruções para autores, constante no final de cada fascículo.}

